\title{
FAKTOR-FAKTOR YANG MEMPENGARUHI KINERJA GURU SEKOLAH MENENGAH KEJURUAN
}

\author{
Hary Susanto \\ SMK Negeri 1 Daha Selatan Kab. Hulu Sungai Selatan Kal-Sel \\ harysusantorzh@yahoo.co.id
}

\begin{abstract}
Abstrak: Faktor-Faktor yang Mempengaruhi Kinerja Guru Sekolah Menengah Kejuruan. Penelitian ini bertujuan untuk mengungkapkan: (1) pengaruh kompetensi guru dan kepemimpinan kepala sekolah terhadap motivasi kerja guru SMK di Kabupaten Hulu Sungai Selatan, Kalimantan Selatan, baik secara sendiri-sendiri maupun bersama-sama, (2) pengaruh kompetensi guru, kepemimpinan kepala sekolah, dan motivasi kerja guru terhadap kinerja guru SMK di Kabupaten Hulu Sungai Selatan, Kalimantan Selatan, baik secara sendiri-sendiri maupun bersama-sama, dan secara langsung atau tidak langsung. Hasil penelitian menunjukkan bahwa terdapat pengaruh positif dan signifikan: (1) kompetensi guru dan kepemimpinan kepala sekolah terhadap motivasi kerja guru SMK di Kabupaten Hulu Sungai Selatan, Kalimantan Selatan, baik secara sendiri-sendiri maupun bersama-sama dengan taraf signifikansi 0,038; 0,045; dan 0,001. (2) kompetensi guru, kepemimpinan kepala sekolah, dan motivasi kerja guru terhadap kinerja guru SMK di Kabupaten Hulu Sungai Selatan, Kalimantan Selatan, baik secara sendiri-sendiri maupun bersama-sama, dan secara langsung atau tidak langsung taraf signifikansi 0,036; 0.003; 0,036; 0,000; (0,038 dan 0,036); (0,045 dan 0,036).
\end{abstract}

Kata kunci : kinerja guru, kompetensi guru, kepemimpinan kepala sekolah, motivasi kerja guru

\section{THE FACTORS OF AFFECTING THE PERFORMANCE OF THE TEACHERS' OF STATE VOCATIONAL HIGH SCHOOL}

\begin{abstract}
The Factors of Affecting the Performance of the Teachers' of State Vocational High School. This study aims to search for the magnitude of, the effect of: (1) the teachers'competence and headmasters' leadership on teachers'work motivation, individually and simultaneously; (2) the effect of the teachers'competence, headmasters' leadership and teachers'work motivation on teachers' performance, individually and simultaneously, and directly and indirectly. The result of the study shows that there is a positive and significant effect of: (1) the teachers'competence and headmasters' leadership on teachers'work motivation, individually and simultaneously with the significance level of 0.038; 0.045; and 0.001. (2) the effect of the teachers'competence, headmasters' leadership and teachers'work motivation on teachers' performance, individually and simultaneously, and directly and indirectly with the significance level of 0.036; 0.003; 0.000; (0.038 and 0.036); (0.045 and 0.036).
\end{abstract}

Keywords : teachers' performance, teachers'competence, headmasters' leadership, teachers' work motivation 


\section{PENDAHULUAN}

Pendidikan pada hakekatnya merupakan salah satu kebutuhan dasar manusia dalam rangka meningkatkan kualitas sumber daya manusia guna pencapaian tingkat kehidupan yang semakin maju dan sejahtera. UndangUndang Nomor 20 tahun 2003 pasal 1 ayat 1 tentang Sistem Pendidikan Nasional mengamanatkan bahwa pendidikan merupakan usaha sadar dan terencana untuk mewujudkan suasana belajar dan proses pembelajaran agar peserta didik secara aktif mengembangkan potensi dirinya untuk memiliki kekuatan spiritual keagamaan, pengendalian diri, kepribadian, kecerdasan, akhlak mulia serta ketrampilan yang dimiliki dirinya, masyarakat, bangsa, dan negara.

Untuk merealisasikan tujuan pendidikan yang diamanatkan oleh Undang-Undang Sistem Pendidikan Nasional tersebut pemerintah menjabarkan dalam program pengembangan sistem pendidikan dasar sampai pendidikan tinggi (pendidikan formal), pendidikan nonformal serta pendidikan informal. Sebagai bagian dari sistem pendidikan nasional sekolah menengah kejuruan merupakan pendidikan menengah yang mempersiapkan peserta didik terutama untuk bekerja dalam bidang tertentu, dapat beradaptasi di lingkungan kerja, dapat melihat peluang kerja dan dapat mengembangkan diri di kemudian hari. Tujuan Sekolah Menengah Kejuruan (SMK) tersebut direalisasikan dengan struktur kurikulum yang memuat tiga program yaitu program normatif, adaptif, dan produktif.
Salah satu faktor mendasar yang menentukan ketercapainya tujuan pendidikan nasional di atas adalah guru. Peran guru menjadi salah satu komponen yang penting dan strategis melalui kinerjanya. Kinerja guru sangat penting dalam mewujudkan tujuan pendidikan nasional dan menentukan tinggi rendahnya mutu pendidikan, akan tetapi kinerja guru ini banyak dipengaruhi oleh berbagai faktor baik dari dalam maupun dari luar individu yang bersangkutan. Berpijak dari penjelasan di atas, maka kondisi kinerja guru-guru SMK di Kabupaten Hulu Sungai Selatan Kalimantan Selatan dihadapkan pada berbagai permasalahan. Permasalahan yang ada secara konkrit dapat diamati pada faktor motivasi kerja guru, kompetensi guru, dan kepemimpinan kepala sekolah.

Sebagaimana ditemukan fakta tentang keadaan kepangkatan guru pada empat SMK Negeri di Kabupaten Hulu Sungai Selatan, bahwa banyak guru yang berpangkat golongan IVa tetapi hanya sedikit guru yang mencapai pangkat golongan IVb. Hal ini akibat terbatasnya motivasi dan kompetensi untuk membuat penelitian tindakan kelas atau karya tulis ilmiah sebagai persyaratan untuk kenaikan pangkat golongan IVb.

Berikut disajikan data tentang jumlah guru menurut golongan kepangkatan per Kabupaten/Kota di Kalimatan Selatan (http://tunas 63.wordpress.com/ 2010/ 01/ 30/ data - nasional - 2009-jumlah-gurumenurut-golongan/). 
Tabel 1. Jumlah Guru menurut di Kabupaten/Kota Kalimantan Selatan

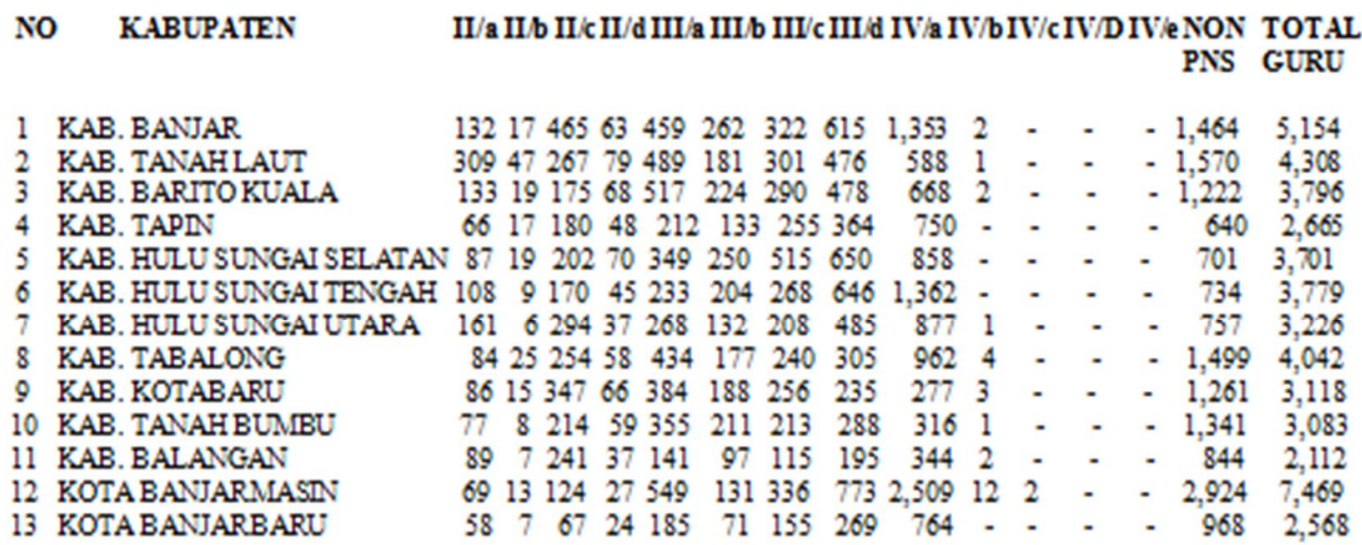

Sumber : SIM NUPTK JUNI 2009 HALAMAN 91

Untuk Kabupaten Hulu Sungai Selatan dari empat SMK Negeri yang ada jumlah guru yang berpangkat golongan IVa mencapai 30,37 $\%$ atau 41 guru dari total jumlah guru yaitu 135 guru. Ditemukan fakta masih terdapat guru yang berlatar belakang pendidikan belum strata satu (S1) atau diploma empat (D-IV). Untuk Kabupaten Hulu Sungai Selatan dari empat SMK Negeri yang ada masih terdapat guru yang belum berpendidikan $\mathrm{S} 1$ atau diploma empat sebesar $8,15 \%$ atau 11 guru dari total jumlah guru yaitu 135 guru. (Laporan bulanan daftar nominatif tenaga edukatif, pembagian tugas guru dalam kegiatan proses belajar mengajar empat SMK Negeri di Kabupaten Hulu Sungai Selatan, Juli 2011).

Di samping itu masih ada guru yang mengajar tidak sesuai dengan latar belakang pendidikan yang dimiliki. Dengan kondisi seperti ini, maka bagi guru yang belum berpendidikan strata satu (S-1) atau diploma empat (D-IV) serta mengajar bidang studi yang tidak sesuai dengan latar belakang pendidikan yang dimiliki tentunya termasuk guru yang belum berkompeten atau belum layak mengajar. Selain itu disiplin kerja guru dalam melaksanakan tugasnya belum sepenuhnya dilakukan dengan baik. Masih terdapat guru yang datang mengajarnya terlambat dan malas mengajar. Meskipun hanya sebagian kecil saja, tetapi hal ini tentu akan mempengaruhi dan mengganggu proses belajar mengajar di sekolah. Selain itu masih ada guru yang datang pada saat jam mengajar saja. Sebagaimana dikemukakan oleh Wardiman Djojonegoro (1998: 52,57) tentang 12 perilaku salah dalam kegiatan belajar mengajar di SMK, diantaranya:, (1) guru tidak membuat lembar kerja atau satuan pelajaran, (2) guru berada di sekolah hanya pada saat jam mengajar.

Dalam mewujudkan kinerja guru yang sesuai dengan harapan dibutuhkan seorang kepala sekolah profesional. Kepala sekolah sebagai bagian dari sistem sekolah menduduki posisi strategis dalam mengarahkan dan mendukung aktivitas guru dalam pembelajaran siswa. Mulyasa (2005: 98) mengatakan bahwa dalam paradigma baru manajemen pendidikan 
kepala sekolah sedikitnya harus mampu berfungsi sebagai edukator, manager, administrator, supervisor, leader, innovator, motivator (EMASLIM).

Dari sejumlah permasalahan tersebut di atas kinerja guru merupakan faktor penting dalam meningkatkan mutu peserta didik, akan tetapi kinerja guru banyak dipengaruhi oleh berbagai faktor, baik yang berasal dari dalam maupun dari luar diri guru. Penelitian ini merupakan sebuah upaya mendapatkan gambaran bagaimana kinerja guru dan faktorfaktor yang mempengaruhi dalam rangka meningkatkan mutu dan kualitas guru Sekolah Menengah Kejuruan, khususnya di Kabupaten Hulu Sungai Selatan (HSS) Kalimantan Selatan.

\section{Kinerja guru}

Dalam Undang-Undang Nomor 14 tahun 2005 Bab 1 pasal 1 tentang guru dan dosen, disebutkan guru adalah pendidik profesional dengan tugas utama mendidik, mengajar, membimbing, mengarahkan, melatih, menilai, dan mengevaluasi peserta didik pada pendidikan anak usia dini jalur pendidikan formal, pendidikan dasar, dan pendidikan menengah.

Menurut Byars dan Rue (1991: 250) "Performance refers to degree of accomplishment of the tasks that make up an individual's job. It reflects how well an individual is fulfilling the requirements of a job”. Pendapat Byars dan Rue diartikan bahwa kinerja atau performance mengacu pada derajat tingkat penyelesaian tugas yang melengkapi pekerjaan seseorang. Hal ini mencerminkan seberapa baik seseorang dalam melaksanakan tuntutan suatu pekerjaan.

Persyaratan penilaian kinerja harus memenuhi ukuran atau standar tertentu. Artinya ukuran kinerja dilakukan sesuai dengan indikator kinerja sebagai alat ukur. Menurut Mitchell dan Larson (1987: 491) "Area of performance is quality of work, promptness, initiative, capability and communication". Artinya wilayah (indikator) penilaian kinerja adalah kualitas hasil kerja, ketepatan waktu menyelesaikan pekerjaan, inisiatif/prakarsa dalam menyelesaikan pekerjaan, kemampuan menyelesaikan pekerjaan, dan komunikasi/kemampuan membina kerjasama dengan pihak lain.

Penilaian kinerja seorang guru merupakan bagian penting dari seluruh proses kinerja guru yang bersangkutan. Menurut Martinis Yamin dan Maisah (2010: 117-125) beberapa sumber penilaian tenaga kependidikan adalah: (1) penilaian atas diri sendiri; (2) penilaian oleh siswa; (3) penilaian oleh rekan sejawat; dan (4) penilaian oleh atasan langsung.

\section{Kompetensi Guru}

Kompetensi guru merupakan suatu kemampuan dasar yang harus dimiliki seorang guru untuk melaksanakan tugas sebagai pengajar dan pendidik. Mulyasa (2009: 26) berpendapat bahwa kompetensi adalah kemampuan melaksanakan sesuatu (tugas) yang diperoleh melalui pendidikan. Spencer \& Spencer (1993:

9) berpendapat bahwa

"A competency is an underlying characteristic of an individual that is causally related to criterion-referenced 
effective and/or superior performance in a job or situation".

Artinya kompetensi adalah karakteristik dasar dari seseorang yang saling berhubungan sebab akibat, sehingga merujuk pada efektivitas dan atau kinerja tinggi dalam pekerjaan atau situasi tertentu.

\section{Kepemimpinan Kepala Sekolah}

Menurut Kartini Kartono (2010: 153) kepemimpinan adalah kemampuan untuk memberikan pengaruh yang konstruktif kepada orang lain untuk melakukan satu usaha kooperatif mencapai tujuan yang sudah dicanangkan. Maka seorang pemimpin itu harus mahir melaksanakan kepemimpinannya jika dia ingin sukses dalam melakukan tugas-tugasnya. Salah satu kunci yang sangat menentukan keberhasilan dan kesuksesan suatu sekolah dalam mencapai tujuan yang telah ditetapkan adalah peran kepala sekolah. Suparlan (2006: 34) mengatakan bahwa ada beberapa peran yang harus dimiliki oleh kepala sekolah yaitu EMASLIMDEF (Educator, Manager, Administrator, Supervisor, Leader, Inovator, Motivator, Dinamisator, Evaluator, dan Facilitator).

Seorang kepala sekolah dalam menjalankan kepemimpinan tidak terlepas dari sifat dan karakteristik yang dimiliki oleh masing-masing kepala sekolah. Menurut M.Ngalim Purwanto (2010: 55-57) beberapa sifat yang diperlukan dalam kepemimpinan pendidikan adalah: (1) rendah hati dan sederhana; (2) bersifat suka menolong; (3) sabar dan memiliki kestabilan emosi; (4) percaya pada diri sendiri; (5) jujur, adil, dan dapat dipercaya; dan (6) keahlian dalam jabatan.

$$
\text { Husaini Usman (2006: }
$$

mengemukakan bahwa kepala sekolah merupakan salah satu kunci yang sangat menentukan keberhasilan sekolah dalam mencapai tujuannya. Keberhasilan kepala sekolah dalam mencapai tujuannya secara dominan ditentukan oleh keandalan manajemen sekolah yang bersangkutan, sedangkan keandalan manajemen sekolah sangat dipengaruhi oleh kapasitas kepemimpinan kepala sekolahnya.

\section{Motivasi Kerja Guru}

Luthans (2008: 158) mengemukakan bahwa

"Motivation is a process that starts with a physiological or psychological deficiency or need that activates a behavior or a drive that is aimed at a goal or incentive".

Menurut Luthan motivasi adalah suatu proses yang dimulai dengan kekurangan kegiatan kehidupan atau kebutuhan jiwa atau kebutuhan yang mengaktifkan perilaku/tekad yang mengarah pada suatu tujuan atau dorongan . Husaini Usman (2006: 223) menyatakan bahwa motivasi kerja dapat diartikan sebagai keinginan atau kebutuhan yang melatarbelakangi seseorang sehingga ia terdorong untuk bekerja.

\section{METODE}

Penelitian ini merupakan penelitian $e x$ post facto, mengungkap hubungan antara variabel kompetensi guru, kepemimpinan kepala sekolah, dan motivasi kerja guru sebagai variabel bebas dengan variabel kinerja guru 
sebagai variabel terikatnya, sehingga termasuk penelitian korelasi dengan menggunakan analisis jalur. Penelitian dilaksanakan di Sekolah Menengah Kejuruan di Kabupaten Hulu Sungai Selatan Kalimantan Selatan yang meliputi: SMKN 1 Kandangan, SMKN 2 Kandangan, SMKN 1 Daha Selatan, dan SMKN 1 Loksado. Penelitian dilaksanakan pada bulan Januari 2012.

Populasi dalam penelitian ini adalah semua guru SMKN di Kabupaten Hulu Sungai Selatan Kalimantan Selatan yang berstatus sebagai Pegawai Negeri Sipil (PNS) yang terdiri dari empat SMKN. Berdasarkan data yang diperoleh dari empat SMKN di Kabupaten Hulu
Sungai Selatan, jumlah seluruh guru pada keempat SMKN tersebut adalah 135 guru. Penentuan sampel penelitian dilakukan dengan teknik proportional random sampling. Menurut Sugiyono (2010: 73) perhitungan sampel tiap sekolah adalah:

Jumlah sampel tiap sekolah $=$ $\frac{\text { Jumlah guru satu sekolah }}{\text { jumlah populasi guru }} \times$ total jumlah sampel

Hasil perhitungan sampel dan sebaran jumlah guru berdasarkan kelompok program mata pelajaran disajikan dalam tabel 5 di bawah ini.

Tabel 2. Sebaran Jumlah Sampel Guru berdasarkan Program Kelompok Mata Pelajaran

\begin{tabular}{|c|c|c|c|c|c|c|c|c|c|}
\hline \multirow{3}{*}{ No } & \multirow{3}{*}{ Nama Sekolah } & \multicolumn{6}{|c|}{ Kelompok Program Mata Pelajaran } & \multirow{2}{*}{\multicolumn{2}{|c|}{$\begin{array}{c}\text { Total } \\
\text { Jumlah Guru }\end{array}$}} \\
\hline & & \multicolumn{2}{|c|}{ Normatif } & \multicolumn{2}{|c|}{ Adaptif } & \multicolumn{2}{|c|}{ Produktif } & & \\
\hline & & Pop & Smpl & Pop & Smpl & Pop & Smpl & Pop & Smpl \\
\hline 1 & $\begin{array}{l}\text { SMKN } 1 \\
\text { Kandangan }\end{array}$ & 13 & 8 & 11 & 10 & 18 & 13 & 42 & 31 \\
\hline 2 & $\begin{array}{l}\text { SMKN } 2 \\
\text { Kandangan }\end{array}$ & 11 & 8 & 17 & 11 & 23 & 17 & 51 & 38 \\
\hline 3 & $\begin{array}{l}\text { SMKN } 1 \text { Daha } \\
\text { Selatan }\end{array}$ & 6 & 5 & 12 & 9 & 7 & 5 & 25 & 19 \\
\hline 4 & SMKN 1 Loksado & 5 & 4 & 8 & 6 & 4 & 3 & 17 & 13 \\
\hline \multicolumn{2}{|c|}{ Jumlah } & 35 & 27 & 48 & 36 & 52 & 38 & 135 & 101 \\
\hline
\end{tabular}

Terdapat dua jenis variabel dalam penelitian ini, yaitu variabel bebas terdiri dari kompetensi guru $\left(\mathrm{X}_{1}\right)$, kepemimpinan kepala sekolah $\left(\mathrm{X}_{2}\right)$, dan motivasi kerja guru $\left(\mathrm{X}_{3}\right)$. Sedangkan variabel terikatnya adalah kinerja guru (Y). Pada penelitian ini pendekatan yang digunakan adalah pendekatan kuantitatif. Untuk mencapai tujuan penelitian ini, maka digunakan metode pengumpulan data, yaitu metode kuesioner atau angket untuk semua variabel dalam bentuk pertanyaan dan dilengkapi dengan jawaban. Skala instrumen yang digunakan adalah skala Likert. Untuk skala Likert, skor tertinggi tiap butir adalah 4 dan yang terendah adalah 1 (Djemari Mardapi, 2004: 115).

Suatu instrumen dinyatakan valid apabila instrumen tersebut dapat digunakan untuk mengukur apa yang diukur. Menurut Sugiono 
(2011: 190) bila koefisien korelasi (r) sama dengan 0,3 atau lebih (paling kecil 0,3) atau $r \geq$ 0,3 maka butir instrumen dinyatakan valid. Bila harga korelasi di bawah 0,30 maka butir-butir instrumen tersebut tidak valid, sehingga harus diperbaiki atau dibuang. Validitas instrumen yang digunakan dalam penelitian ini adalah validitas isi (content validity) dan validitas konstrak (construct validity) dari masing-masing variabel.Untuk menguji validitas isi dan validasi konstrak instrumen dalam penelitian ini dilakukan dengan expert judgment atau pertimbangan ahli.Para ahli dalam hal ini adalah dosen pembimbing dan dosen lain yang berkompeten. Dua ahli sebagai validator instrumen ini adalah Dr. Wagiran dan Dr. Lantif Diat Prasojo.

Instrumen yang telah disusun kemudian dilakukan uji coba instrumen pada 30 orang responden. Uji coba bertujuan untuk mengetahui validitas dan releabilitas instrumen tersebut, dan dilakukan pada responden terpakai yang biasa disebut ujicoba terpakai. Dari hasil uji coba ini kemudian dilakukan analisis butir, dengan cara mengkorelasikan skor butir (X) terhadap skor total instrumen (Y). Analisis ini menggunakan formula korelasi product moment Karl Pearson. Proses analisis validitas instrument dalam penelitian ini menggunakan bantuan komputer program SPSS versi 13.0 for windows

Pengujian reliabilitas bertujuan untuk memperoleh instrumen yang benar-benar dapat dipercaya atau handal. Uji reliabilitas dilakukan setelah uji validitas, sehingga hanya butir yang valid saja yang di uji. Kriteria yang digunakan untuk menetapkan reliabilitas instrumen adalah indeks kehandalan instrumen dengan formula Cronbach Alpha. Apabila besarnya indek kehandalan instrumen sama atau lebih besar dari 0,7 maka instrumen itu tergolong baik (Djemari Mardapi 2008: 122,125).

Instrumen kinerja guru terdiri dari 35 butir pernyataan. Berdasarkan hasil analisis data terdapat 3 butir pernyataan yang tidak valid yaitu no: 19, 20, dan 25. Instrumen kompetensi guru terdiri dari 42 butir pernyataan, terdapat 2 butir pernyataan yang tidak valid yaitu no: 9 dan 31. Sedangkan untuk instrumen kepemimpinan kepala sekolah dan motivasi kerja guru valid semua. Hasil analisa data menunjukkan bahwa instrumen kinerja guru, kompetensi guru, kepemimpinan kepala sekolah, dan motivasi kerja guru memiliki koefisien alpha masingmasing sebesar 0,$938 ; 0,965 ; 0,962$; dan 0,947.

Teknik analisis data yang digunakan dalam penelitian ini adalah teknik analisis dengan menggunakan analisis jalur atau path analysis yaitu analisis untuk mengetahui pengaruh secara langsung dan tidak langsung variabel bebas terhadap variabel terikat dengan menggunakan regresi linear berganda.

Uji persyaratan analisis pada penelitian ini adalah uji normalitas, uji lineritas, dan uji multikolinearitas. Uji normalitas dilakukan untuk mengetahui apakah data yang diperoleh dari hasil penelitian berdistribusi normal atau tidak. Uji normalitas dalam penelitian ini dilakukan dengan menggunakan uji Kolmogorov-Smirnov. Pengambilan keputusan dilakukan jika nilai signifikansi lebih besar dari $0,05(\rho>0,05)$ maka distribusi data dinyatakan normal (Singgih Santoso, 2000: 102). 
Uji linearitas dilakukan untuk mengetahui apakah data masing-masing variabel bebas mempunyai hubungan yang linear dengan variabel terikat. Pedoman yang digunakan adalah jika nilai signifikansi pada lajur deviation from linearity > 0,05 maka disimpulkan hubungan variabel bebas dengan variabel terikat linier (Triton, 2006: 163). Uji multikolinearitas dilakukan untuk mengetahui besarnya harga interkorelasi antara sesama variabel bebas. Imam Ghozali (2001:63) menyatakan bahwa gejala multikolinieritas dapat dilihat dari nilai tolerance dan variance inflation factor (VIF). Variabel bebas yang memiliki nilai variance inflation factor (VIF) lebih kecil dari 10 $(\mathrm{VIF}<10)$ dapat disimpulkan tidak terjadi multikolinearitas.

Analisa korelasi dalam penelitian ini digunakan untuk mencari hubungan antara masing-masing variabel bebas $\left(\mathrm{X}_{1}\right),\left(\mathrm{X}_{2}\right)$, dan $\left(\mathrm{X}_{3}\right)$ dengan variabel terikat $(\mathrm{Y})$. Analisa data pada penelitian ini menggunakan analisis jalur (path analysis) dengan bantuan komputer program SPSS versi 13.0 for Windows. Sedangkan analisis jalur dalam penelitian ini digunakan untuk mengetahui pengaruh langsung, pengaruh tidak langsung dan pengaruh total variabel bebas (eksogen) terhadap variabel terikat (endogen).

Untuk melihat pengaruh langsung variabel bebas terhadap variabel terikat baik secara simultan/bersama-sama atau secara parsial/sendiri-sendiri menggunakan regresi linear berganda. Untuk melihat pengaruh variabel bebas terhadap variabel terikat secara tidak langsung melalui variabel intervening dilakukan dengan menggunakan analisis jalur (path analysis). Menurut Bhuono Agung Nugroho (2005: 52) pedoman yang digunakan untuk menerima atau menolak hipotesis jika hipotesis nol (Ho) yang diusulkan: Ho diterima jika $\mathrm{F}$ atau t-hitung < F atau t-tabel, atau nilai $\rho$ value pada kolom sig. > level of significant $(\alpha)$, dan Ho ditolak jika $\mathrm{F}$ atau t-hitung $>\mathrm{F}$ atau ttabel, atau nilai $\rho$ value pada kolom sig. < level of significant $(\alpha)$.

\section{HASIL PENELITIAN}

\section{Kinerja Guru}

Rerata nilai variabel kinerja guru SMK di Kabupaten Hulu Sungai Selatan (HSS) termasuk dalam kategori kecenderungan sangat baik sebesar 108,94 (X $\geq 104)$, dan persentase terbesar perolehan tersebut $66,4 \%$ (67 guru). Distribusi frekuensi perolehan skor kecenderungan kinerja guru terlihat pada gambar 1 di bawah ini.

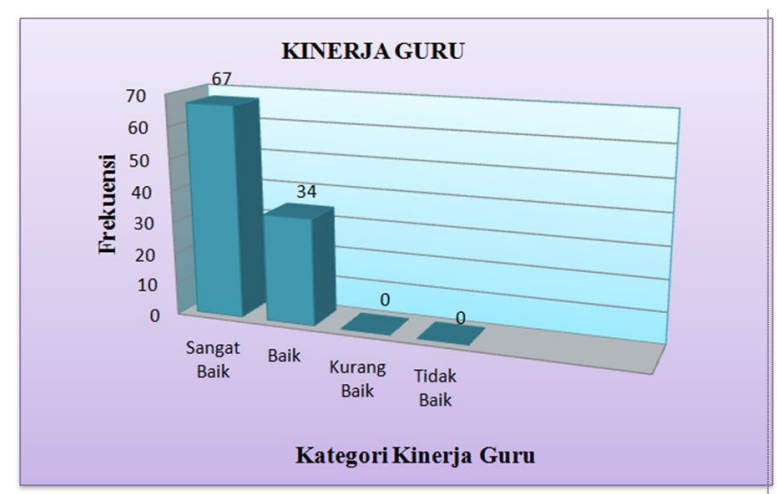

Gambar 1. Diagram Kategori Perolehan Skor Kecenderungan Kinerja Guru

\section{Kompetensi Guru}

Rerata nilai variabel kompetensi guru SMK di Kabupaten Hulu Sungai Selatan (HSS) 
termasuk dalam kategori kecenderungan baik, sebesar 123,46 $(100 \leq X<130)$, dan persentase terbesar perolehan tersebut 69,31\% (70 guru). distribusi frekuensi perolehan skor kecenderungan kompetensi guru terlihat pada gambar 2 di bawah ini.

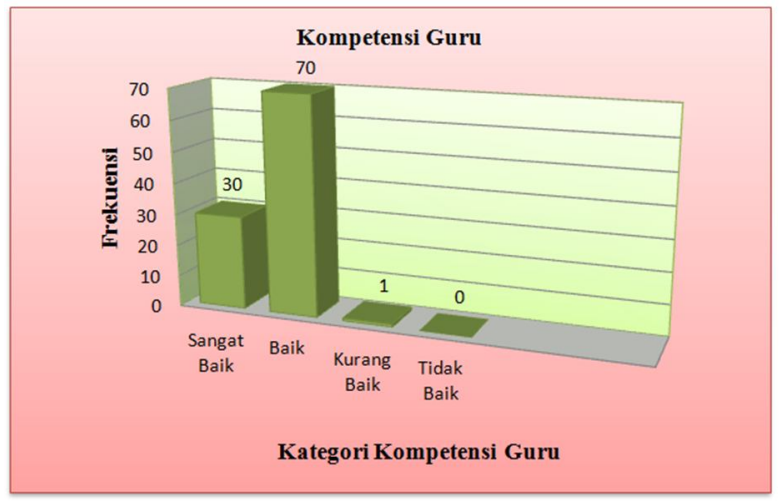

Gambar 2. Diagram Kategori Perolehan Skor Kecenderungan Kompetensi Guru

\section{Kepemimpinan Kepala Sekolah}

Rerata nilai variabel kepemimpinan kepala sekolah SMK di Kabupaten Hulu Sungai Selatan (HSS) termasuk dalam kategori

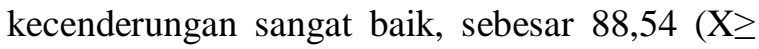
87,75), dan persentase terbesar perolehan tersebut 56,44\% (57 guru). Distribusi frekuensi perolehan skor kecenderungan kepemimpinan kepala sekolah terlihat pada gambar 3 di bawah ini.

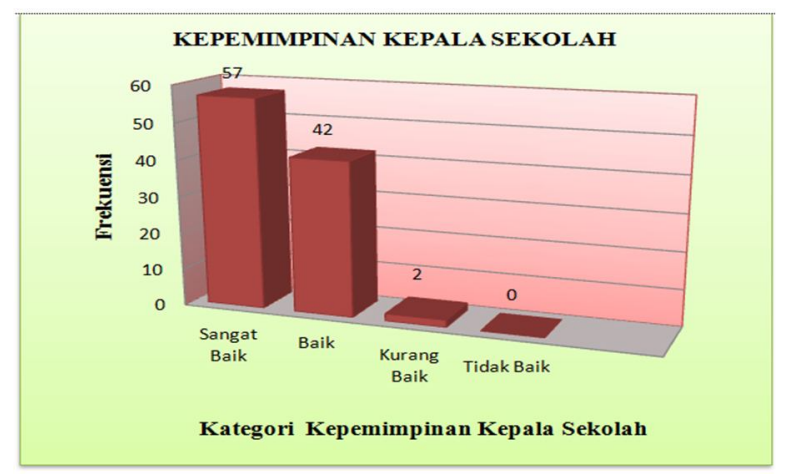

Gambar 3. Diagram Kategori Perolehan Skor Kecenderungan

\section{Motivasi Kerja Guru}

Rerata nilai variabel motivasi kerja guru SMK di Kabupaten Hulu Sungai Selatan (HSS) yang diperoleh dari hasil analisis statistik termasuk dalam kategori kecenderungan baik, sebesar 72,85 (72,5 $\leq X<94,5)$, dan persentase terbesar perolehan tersebut 52,48\% (53 guru). Distribusi frekuensi perolehan skor kecenderungan motivasi kerja guru terlihat pada gambar 4 di bawah ini.

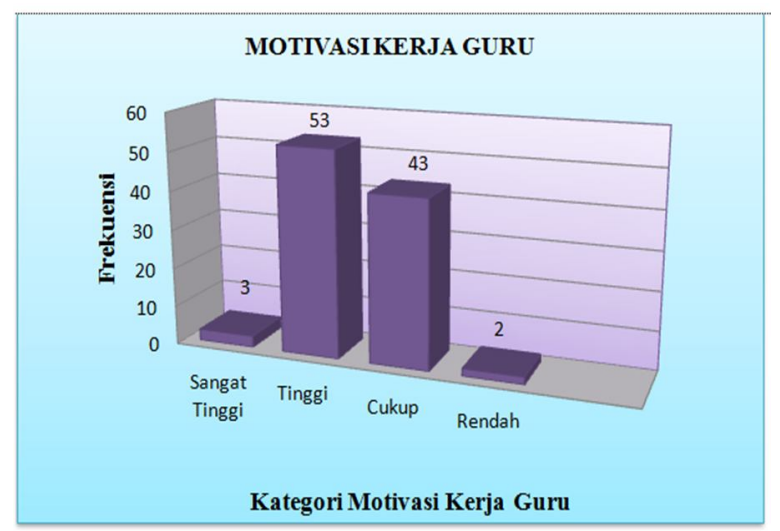

Gambar 4. Diagram Kategori Perolehan Skor Kecenderungan Motivasi Kerja Guru

Hasil uji normalitas dengan uji Kolmogorov Smirnov menunjukkan nilai $\mathrm{X}_{1}, \mathrm{X}_{2}$, $\mathrm{X}_{3}$, Y sebesar 0,199; 0,115;0,859;0,466 $(>0,05)$ dan disimpulkan berdistribusi normal. Hasil uji Linearitas menunjukkan nilai Sig. Deviation from Linearity hubungan variabel $\mathrm{X}_{1}-\mathrm{Y}, \mathrm{X}_{2}-\mathrm{Y}$ dan $\mathrm{X}_{3}$ - Y adalah 0,674; 0,587 dan 0,441 ( > $0,05)$ sehingga disimpulkan terjadi hubungan linear. Sedangkan hasil penghitungan uji multikolinearitas nilai VIF untuk variabel $X_{1}$, $\mathrm{X}_{2}$, dan $\mathrm{X}_{3}$ adalah 1,$256 ; 1,252$; dan 1,148 (< 10), sehingga disimpulkan tidak terjadi multikolinieritas. Adapun hasil penghitungan analisis korelasi seperti pada tabel 3 di bawah ini. 
Tabel 3. Rangkuman Hasil Analisis Korelasi

\begin{tabular}{clccccc}
\hline No & Korelasi & $\begin{array}{c}\text { Kefisien } \\
\text { Korelasi }\end{array}$ & $\begin{array}{c}\text { Tanda } \\
\text { Bintang }\end{array}$ & $\begin{array}{c}\text { Arah } \\
\text { Korelasi }\end{array}$ & $\begin{array}{c}\text { Probabilitas/ } \\
\text { Sig. }(\rho)<0,005\end{array}$ & Kesimpulan \\
\hline \hline 1 & $\mathrm{X}_{1}-\mathrm{X}_{3}$ & 0,304 & ada $* *$ & positif & 0,002 & signifikan \\
2 & $\mathrm{X}_{2}-\mathrm{X}_{3}$ & 0,299 & ada $* *$ & positif & 0,002 & signifikan \\
3 & $\mathrm{X}_{1}-\mathrm{Y}$ & 0,387 & ada $* *$ & positif & 0,000 & signifikan \\
4 & $\mathrm{X}_{2}-\mathrm{Y}$ & 0,438 & ada $* *$ & positif & 0,000 & signifikan \\
5 & $\mathrm{X}_{3}-\mathrm{Y}$ & 0,348 & ada $* *$ & positif & 0,000 & signifikan \\
6 & $\mathrm{X}_{1}-\mathrm{X}_{2}$ & 0,410 & ada $* *$ & positif & 0,000 & signifikan \\
\hline
\end{tabular}

Sumber: Data Primer diolah 2012

Analisis data pada penelitian ini menggunakan analisis jalur (path analysis). Adapun gambaran terhadap diagram jalur hubungan kausal antara variabel bebas $\left(\mathrm{X}_{1}, \mathrm{X}_{2}\right.$, $\mathrm{X}_{3}$ ) dan variabel terikat (Y) seperti pada gambar 5 di bawah ini

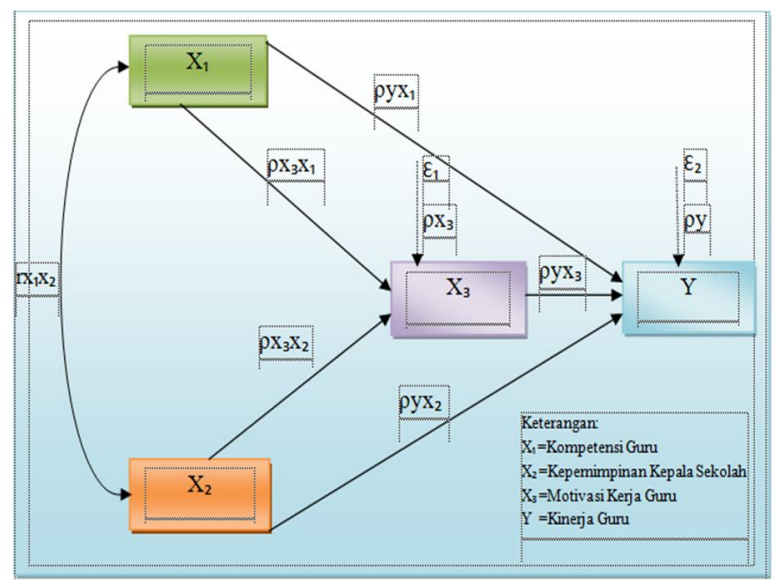

Gambar 5. Diagram Jalur Hubungan Kausal Variabel $\mathrm{X}_{1}, \mathrm{X}_{2}, \mathrm{X}_{3}$, dan $\mathrm{Y}$

Persamaan struktural berdasarkan gambar 5 di atas adalah sebagai berikut:

1. $X_{3}=\rho x_{3} x_{1} X_{1}+\rho x_{3} x_{2} X_{2}+\rho x_{3} \varepsilon_{1}$ (persamaan sub-struktural satu)

2. $Y=\rho \mathrm{yx}_{1} \mathrm{X}_{1}+\rho \mathrm{yx}_{2} \mathrm{X}_{2}+\rho \mathrm{yx}_{3} \mathrm{X}_{3}+\rho \mathrm{y} \varepsilon_{2}$ (persamaan sub-struktural dua)
Hasil analisis regresi linear ganda variabel bebas terhadap variabel terikat pada persamaan sub-struktural satu yaitu $X_{3}=\rho x_{3} X_{1} X_{1}$ $+\rho \mathrm{x}_{3} \mathrm{X}_{2} \mathrm{X}_{2}+\rho \mathrm{X}_{3} \varepsilon_{1}$ disajikan pada disajikan pada tabel 4 di bawah ini.

Tabel 4. Hasil Analisis Regresi Linear Ganda Sub-Struktural Satu Pengaruh Langsung Secara Simultan Variabel $\mathrm{X}_{1}$ dan $\mathrm{X}_{2}$ terhadap $\mathrm{X}_{3}$

\begin{tabular}{cccc}
\hline Variabel & $\begin{array}{c}\text { Keofisien } \\
\text { Determinan } \\
\left(\mathrm{R}^{2}\right)\end{array}$ & $\mathrm{F}_{\text {Hitung }}$ & $\begin{array}{c}\text { Nilai Sig. }(\rho) \\
(\rho<0,05)\end{array}$ \\
\hline $\mathrm{X}_{1}, \mathrm{X}_{2},-\mathrm{X}_{3}$ & 0,129 & 7,255 & $0,001<0,005$ \\
\hline
\end{tabular}

Berdasarkan tabel 5 di atas, maka sumbangan efektif $X_{1}$ dan $X_{2}$ terhadap $X_{3}$ secara simultan/bersama-sama adalah sebesar $12,9 \%$. Sementara sisanya sebesar $87,1 \%(100 \%$ - 12,9\%) $\mathrm{X}_{3}$ dipengaruhi oleh faktor lain. Hasil analisis regresi linear ganda variabel bebas terhadap variabel terikat pada persamaan substruktural satu untuk mengetahui pengaruh langsung secara parsial $\mathrm{X}_{1}$ dan $\mathrm{X}_{2}$ terhadap $\mathrm{X}_{3}$ disajikan pada pada tabel 5 di bawah ini. 
Tabel 5. Hasil Analisis Regresi Linear Ganda Sub-Struktural Satu Pengaruh Langsung Secara Parsial Variabel $X_{1}$ dan $X_{2}$ terhadap $X_{3}$

\begin{tabular}{cccccc}
\hline Variabel & $\begin{array}{c}\text { Keofisien } \\
\text { Regresi }\end{array}$ & $\begin{array}{c}\text { Koefisien } \\
\text { Korelasi }\end{array}$ & $\begin{array}{c}\text { Beta/Koefisien } \\
\text { Jalur }\end{array}$ & $t_{\text {Hitung }}$ & $\begin{array}{c}\text { Nilai Sig. }(\rho) \\
(\rho<0,05)\end{array}$ \\
\hline \hline $\mathrm{X}_{1}-\mathrm{X}_{3}$ & 0,171 & 0,304 & $0,218\left(\rho \mathrm{x}_{1} \mathrm{x}_{3}\right)$ & 2,106 & 0,038 \\
$\mathrm{X}_{2}-\mathrm{X}_{3}$ & 0,212 & 0,299 & $0,210\left(\rho \mathrm{x}_{1} \mathrm{x}_{3}\right)$ & 2,033 & 0,045 \\
\hline
\end{tabular}

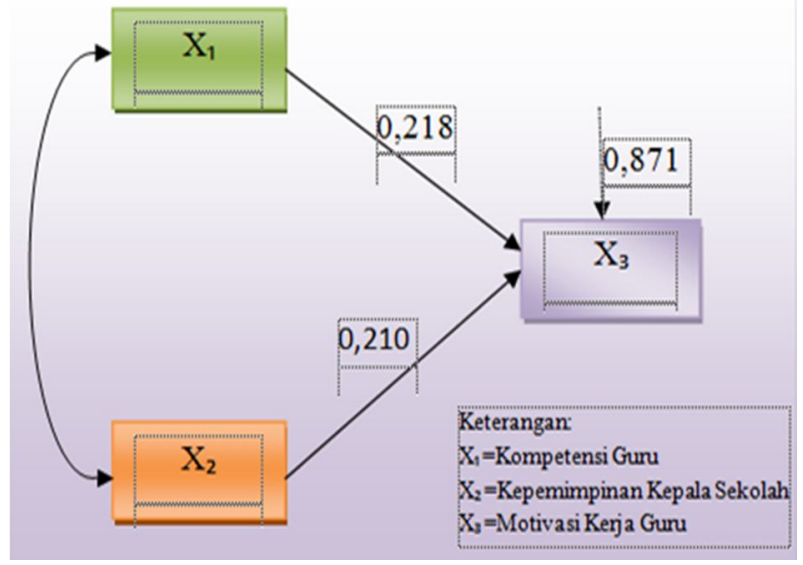

Gambar 6. Gambaran Diagram Nilai Koefisien Jalur Sub-Struktural Satu Variabel $\mathrm{X}_{1}$ dan $\mathrm{X}_{2}$ terhadap $\mathrm{X}_{3}$

Berdasarkan hasil tersebut maka persamaan struktural yang diperoleh adalah sebagai berikut: $X_{3}=0,218 X_{1}+0,210 X_{2}+0,871 \varepsilon_{1}$

Hasil penghitungan regresi linear ganda persamaan sub-struktural dua yaitu $Y=\rho \mathrm{yx}_{1} \mathrm{X}_{1}+\rho \mathrm{yx}_{2} \mathrm{X}_{2}+\rho \mathrm{yx}_{3} \mathrm{X}_{3}+\rho \mathrm{y} \varepsilon_{2} \quad$ untuk pengaruh langsung secara simultan atau gabungan $\mathrm{X}_{1}, \mathrm{X}_{2}$, dan $\mathrm{X}_{3}$ terhadap $\mathrm{Y}$ disajikan pada tabel 6 di bawah ini.
Tabel 6. Hasil Analisis Regresi Linear Ganda Sub-Struktural Dua Pengaruh Langsung Secara Simultan Variabel $\mathrm{X}_{1}, \mathrm{X}_{2}$ dan $\mathrm{X}_{3}$ terhadapY

\begin{tabular}{cccc}
\hline Variabel & $\begin{array}{c}\text { Keofisien } \\
\text { Determinan } \\
\left(\mathrm{R}^{2}\right)\end{array}$ & $\mathrm{F}_{\text {Hitung }}$ & $\begin{array}{c}\text { Nilai Sig. }(\rho) \\
(\rho<0,05)\end{array}$ \\
\hline \hline $\mathrm{X}_{1}, \mathrm{X}_{2}, \mathrm{X}_{3-} \mathrm{Y}$ & 0,277 & 12,404 & $0,000<0,005$ \\
\hline
\end{tabular}

Berdasarkan tabel 5 di atas, maka sumbangan efektif $\mathrm{X}_{1}, \mathrm{X}_{2}, \mathrm{X}_{3}$ terhadap $\mathrm{Y}$ secara simultan/bersama-sama adalah sebesar $27,7 \%$. Sementara sisanya sebesar $72,3 \%$ (100\% - 27,7\%) Y dipengaruhi oleh faktor lain. Hasil penghitungan regresi linear ganda persamaan sub-struktural dua untuk mengetahui pengaruh langsung secara parsial atau individu $\mathrm{X}_{1}, \mathrm{X}_{2}$, dan $\mathrm{X}_{3}$ terhadap $\mathrm{Y}$ disajikan pada tabel $7 \mathrm{di}$ bawah ini.

Tabel 7. Hasil Analisis Regresi Linear ganda Sub-Struktural Dua Pengaruh Langsung Secara Parsial Variabel $\mathrm{X}_{1}, \mathrm{X}_{2}$, dan $\mathrm{X}_{3}$ terhadap $\mathrm{Y}$

\begin{tabular}{cccccc}
\hline \hline Variabel & $\begin{array}{c}\text { Keofisien } \\
\text { Regresi }\end{array}$ & $\begin{array}{c}\text { Koefisien } \\
\text { Korelasi }\end{array}$ & $\begin{array}{c}\text { Beta/Koefisien } \\
\text { Jalur }\end{array}$ & t $_{\text {Hitung }}$ & $\begin{array}{c}\text { Nilai Sig. }(\rho) \\
(\rho<0,05)\end{array}$ \\
\hline \hline $\mathrm{X}_{1}-\mathrm{Y}$ & 0,158 & 0,387 & $0,206\left(\rho \mathrm{yx}_{1}\right)$ & 2,106 & 0,036 \\
$\mathrm{X}_{2}-\mathrm{Y}$ & 0,291 & 0,438 & $0,0,295\left(\rho \mathrm{yx}_{2}\right)$ & 2,033 & 0,003 \\
$\mathrm{X}_{3}-\mathrm{Y}$ & 0,193 & 0,348 & $0,197\left(\rho \mathrm{yx}_{3}\right)$ & 2,132 & 0,036 \\
\hline
\end{tabular}




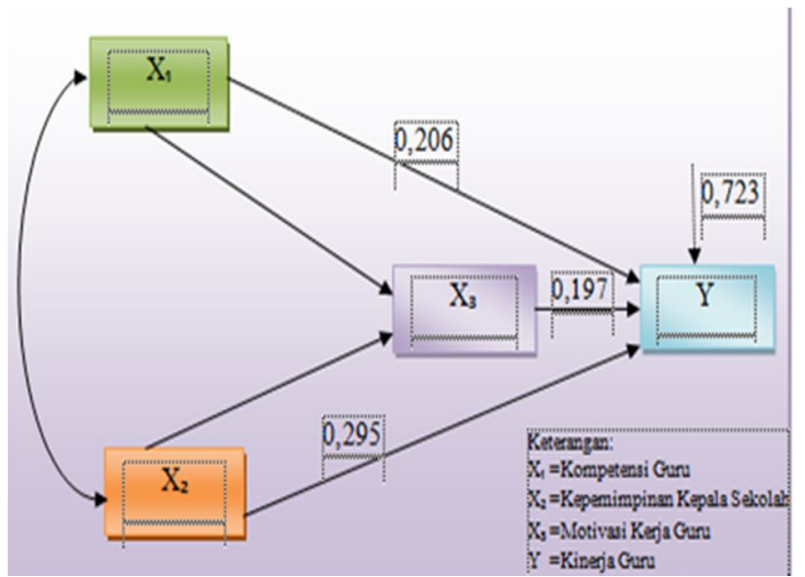

Gambar 7. Gambaran Diagram Nilai Koefisien Jalur Sub-Struktural Dua Variabel $\mathrm{X}_{1}, \mathrm{X}_{2}$, dan $\mathrm{X}_{3}$ terhadap $\mathrm{Y}$
Berdasarkan hasil tersebut maka persamaan struktural yang diperoleh adalah sebagai berikut: $Y=0,206 X_{1}+0,295 X_{2}+$ $0,197 X_{3}+0,723 \varepsilon_{2}$. Hasil analisis jalur dengan regresi linear ganda untuk pengaruh tidak langsung kompetensi guru $\mathrm{X}_{1}$ terhadap $\mathrm{Y}$ melalui $\mathrm{X}_{3}$ disajikan pada tabel 8 .

Tabel 8. Hasil Analisis Jalur Variabel Kompetensi Guru $\left(\mathrm{X}_{1}\right)$ terhadap Kinerja Guru (Y) melalui Motivasi Kerja Guru $\left(\mathrm{X}_{3}\right)$

\begin{tabular}{cccccc}
\hline Variabel & $\begin{array}{c}\text { Keofisien } \\
\text { Regresi }\end{array}$ & $\begin{array}{c}\text { Koefisien } \\
\text { Korelasi }\end{array}$ & $\begin{array}{c}\text { Beta/Koefisien } \\
\text { Jalur }\end{array}$ & t $_{\text {Hitung }}$ & $\begin{array}{c}\text { Nilai Sig. }(\rho) \\
(\rho<0,05)\end{array}$ \\
\hline \hline $\mathrm{X}_{1}-\mathrm{X}_{3}$ & 0,171 & 0,304 & $0,218\left(\rho \mathrm{yx}_{1)}\right.$ & 2,106 & 0,038 \\
$\mathrm{X}_{3}-\mathrm{Y}$ & 0,193 & 0,348 & $0,197\left(\rho \mathrm{yx}_{3}\right)$ & 2,132 & 0,036 \\
\hline
\end{tabular}

Besarnya pengaruh tidak langsung $X_{1}$ terhadap Y melalui $\mathrm{X}_{3}$ adalah sebesar $0,218 \mathrm{x}$ $0,197=0,043$. Hasil analisis analisis jalur dengan regresi linear ganda untuk pengaruh tidak langsung variabel $\mathrm{X}_{2}$ terhadap $\mathrm{Y}$ melalui $\mathrm{X}_{3}$ disajikan pada tabel 9 di bawah ini.

Tabel 9. Hasil Analisis Jalur Variabel Kepemimpinan kepala sekolah $\left(\mathrm{X}_{2}\right)$ terhadap Kinerja Guru (Y) melalui Motivasi Kerja Guru ( $\left.\mathrm{X}_{3}\right)$

\begin{tabular}{cccccc}
\hline \hline Variabel & $\begin{array}{c}\text { Keofisien } \\
\text { Regresi }\end{array}$ & $\begin{array}{c}\text { Koefisien } \\
\text { Korelasi }\end{array}$ & $\begin{array}{c}\text { Beta/Koefisien } \\
\text { Jalur }\end{array}$ & t $_{\text {Hitung }}$ & $\begin{array}{c}\text { Nilai Sig. }(\rho) \\
(\rho<0,05)\end{array}$ \\
\hline \hline $\mathrm{X}_{2}-\mathrm{X}_{3}$ & 0,212 & 0,299 & $0,210\left(\rho \mathrm{yx}_{1)}\right.$ & 2,033 & 0,045 \\
$\mathrm{X}_{3}-\mathrm{Y}$ & 0,193 & 0,348 & $0,197\left(\rho \mathrm{yx}_{3}\right)$ & 2,132 & 0,036 \\
\hline
\end{tabular}

Besarnya pengaruh tidak langsung $X_{2}$ terhadap $\mathrm{Y}$ melalui $\mathrm{X}_{3}$ adalah sebesar $0,210 \mathrm{x}$ $0,197=0,041$. Besarnya pengaruh total $X_{1}$ terhadap $\mathrm{Y}$ secara langsung dan tidak langsung adalah sebesar $0,206+0,043=0,249$. Sedangkan besarnya pengaruh total $\mathrm{X}_{2}$ terhadap
Y secara langsung dan tidak langsung adalah sebesar $0,295+0,041=0,336$.

Tabel 10 di bawah ini merangkum seluruh hasil koefisien jalur pengaruh langsung, pengaruh tidak langsung, dan pengaruh total antara $\mathrm{X}_{1}, \mathrm{X}_{2}, \mathrm{X}_{3}$, dan $\mathrm{Y}$ pada sub - struktural satu dan sub - struktural dua. 
Tabel 10. Hasil Koefisien Jalur Pengaruh Langsung, Pengaruh Tidak Langsung dan Pengaruh Total antara Variabel $\mathrm{X}_{1}, \mathrm{X}_{2}, \mathrm{X}_{3}$, dan $\mathrm{Y}$.

\begin{tabular}{lcccc}
\hline \multicolumn{1}{c}{ Variabel } & Koefisien Jalur & \multicolumn{3}{c}{ Pengaruh } \\
Tidak Langsung & Total \\
\hline \hline $\mathrm{X}_{1}$ terhadap $\mathrm{X}_{3}$ & 0,218 & 0,218 & - & 0,218 \\
$\mathrm{X}_{2}$ terhadap $\mathrm{X}_{3}$ & 0,210 & 0,210 & - & 0,210 \\
$\mathrm{X}_{1}$ terhadap Y & 0,206 & 0,206 & $0,218 \times 0,917=0,043$ & 0,249 \\
$\mathrm{X}_{2}$ terhadap Y & 0,295 & 0,295 & $0,210 \times 0,197=0,041$ & 0,336 \\
$\mathrm{X}_{3}$ terhadap Y & 0,197 & 0,197 & - & 0,197 \\
$\varepsilon_{1}$ & 0,873 & 0,873 & - & 0,873 \\
$\varepsilon_{2}$ & 0,723 & 0,723 & - & 0,723 \\
\hline
\end{tabular}

Gambar 8 di bawah ini memberikan gambaran tentang hasil analisis jalur antara variabel $X_{1}$ dan $X_{2}$ terhadap $X_{3}$, serta hasil analisis jalur antara variabel $X_{1}, X_{2}$, dan $X_{3}$ terhadap Y.

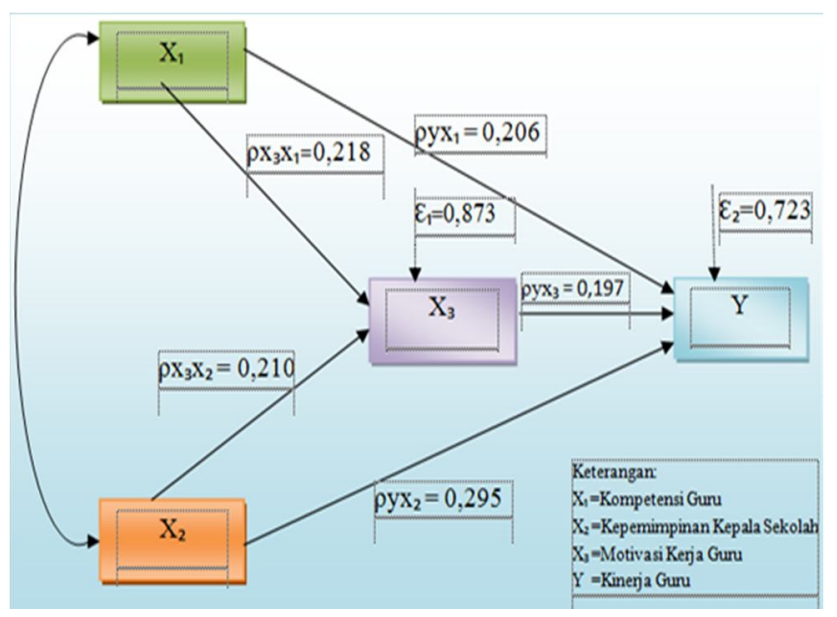

Gambar 8. Gambaran Hasil Analisis Jalur Variabel $\mathrm{X}_{1}, \mathrm{X}_{2}$ terhadap $\mathrm{X}_{3}$ dan Variabel $\mathrm{X}_{1}, \mathrm{X}_{2}$ dan $\mathrm{X}_{3}$ terhadap $\mathrm{Y}$

Menurut Suwarno (Haryadi Sarjono dan Winda Julianita, 2011: 117) kategori pengaruh setiap variabel independen (bebas) terhadap variabel dependen (terikat) dalam model ditetapkan seperti pada tabel 11 di bawah ini.

Tabel 11. Kategori Hubungan Pengaruh Variabel yang Diteliti

\begin{tabular}{ll}
\hline \hline Koefisien Path & Daya/Pengaruh \\
\hline \hline $0,05-0,09$ & Lemah \\
$0,10-0,29$ & Sedang \\
$>0,30$ & Kuat \\
\hline
\end{tabular}

Sumber: Suwarno (Haryadi \& Winda, 2011:117)

Berdasarkan hasil penghitungan yang dilakukan, maka nilai koefisien path atau koefisien jalur hubungan pengaruh langsung antara variabel independen (bebas) terhadap variabel dependen (terikat) ada pada kategori daya atau pengaruh sedang.Sedangkan nilai koefisien path atau koefisien jalur hubungan pengaruh tidak langsung antara variabel independen (bebas) terhadap variabel dependen (terikat) melalui variabel intervening (perantara) tidak termasuk pada ketiga kategori yang ada karena nilai koefisien path kurang dari 0,05 $(<0,05)$, sehingga dapat diambil kesimpulan 
bahwa hasil koefisien path tersebut mempunyai daya atau pengaruh sangat lemah. Adapun untuk hasil pengaruh total variabel $\mathrm{X}_{1}$ terhadap $\mathrm{Y}$ melalui $\mathrm{X}_{3}$ ada pada kategori daya atau pengaruh sedang dan pengaruh total variabel $\mathrm{X}_{2}$ terhadap $\mathrm{Y}$ melalui $\mathrm{X}_{3}$ berada pada kategori daya atau pengaruh kuat.

\section{PEMBAHASAN}

\section{Kinerja Guru}

Hasil dalam penelitian ini menunjukkan bahwa 66,34\% (67 guru) SMK di Kabupaten Hulu Sungai Selatan memiliki kinerja dalam kategori sangat baik; 33,66\% (34 guru) dalam kategori baik; dan tidak ada yang termasuk dalam kategori kurang baik dan tidak baik. Hasil di atas dapat diartikan bahwa sebagian besar guru SMK di Kabupaten Hulu Sungai Selatan Kalimantan Selatan telah melaksanakan tugas dan fungsinya dengan sangat baik. Kinerja guru ditunjukkan oleh para guru dalam melaksanakan tugas sehari-hari yang menjadi tanggung jawabnya.

\section{Kompetensi Guru}

Hasil pada penelitian ini menunjukkan bahwa 29,70\% (30 guru) SMK di Kabupaten Hulu Sungai Selatan mempunyai kompetensi dalam kategori sangat baik; 69,31\% (70 guru) dalam kategori baik; 0,99\% (1 guru) dalam kategori kurang baik; dan tidak ada yang termasuk dalam kategori tidak baik. Berdasarkan hasil penelitian tersebut dapat diartikan bahwa secara umum guru SMK di Kabupaten Hulu Sungai Selatan dalam melaksanakan tupoksi atau tugas pokok dan fungsinya sudah memiliki kompetensi yang baik.

\section{Kepemimpinan kepala sekolah}

Hasil pada penelitian ini mengungkapkan bahwa kepemimpinan kepala sekolah (menurut persepsi guru) dikategorikan sangat baik. Hal ini ditunjukkan oleh $56,44 \%$ (57 guru) berpendapat bahwa kepemimpinan kepala sekolah di Kabupaten Hulu Sungai Selatan dalam kategori sangat baik; 41,58\% (42 guru) berpendapat dalam kategori baik; dan 1,98 \% (2 guru) berpendapat kepemimpinan kepala sekolah dalam kategori kurang baik. Tidak ada pendapat tentang kepemimpinan kepala sekolah yang termasuk dalam kategori tidak baik. Berdasarkan hasil penelitian tersebut dapat diartikan bahwa secara umum kepemimpinan kepala sekolah SMK di Kabupaten Hulu Sungai Selatan (menurut persepsi guru) di dalam menjalankan tugas yang menjadi tanggungjawabnya dilaksanakan dengan baik

\section{Motivasi Kerja Guru}

Hasil pada penelitian ini mengungkapkan bahwa 2,97\% (3 guru) SMK di Kabupaten Hulu Sungai Selatan memiliki motivasi kerja dalam kategori sangat tinggi; 52,48\% (53 guru) dalam kategori tinggi; 42,57\% (43 guru) dalam kategori cukup; dan 1,98 \% (2 guru) dalam kategori rendah. Berdasarkan hasil penelitian tersebut dapat diartikan bahwa sebagian besar guru SMK di Kabupaten Hulu Sungai Selatan dalam melaksanakan tugas dan fungsinya memiliki motivasi kerja yang tinggi. 


\section{SIMPULAN}

1. Analisis deskriptif tentang skor kategori variabel bebas (eksogen) dan variabel terikat (endogen) adalah sebagai berikut (a) kinerja guru SMK di Kabupaten Hulu Sungai Selatan Kalimantan Selatan secara umum dalam kategori sangat baik yang ditunjukkan oleh rerata nilai kinerja guru 108,94 ( $\mathrm{X} \geq 104)$ dan persentase terbesar perolehan tersebut (66,4\%); (b) Kompetensi guru SMK di Kabupaten Hulu Sungai Selatan Kalimantan Selatan secara umum dalam kategori baik yang ditunjukkan oleh rerata nilai kompetensi guru 123,46 $(100 \leq \mathrm{X}<130)$ dan persentase terbesar perolehan tersebut (69,31\%); (c) kepemimpinan kepala sekolah SMK di Kabupaten Hulu Sungai Selatan Kalimantan Selatan secara umum dalam kategori sangat baik yang ditunjukkan oleh rerata nilai kepemimpinan kepala sekolah $(88,54),(X \geq 87,75)$ dan persentase terbesar perolehan tersebut $(56,44 \%)$; (d) motivasi kerja guru SMK di Kabupaten Hulu Sungai Selatan Kalimantan Selatan secara umum dalam kategori tinggi yang ditunjukkan oleh rerata nilai motivasi kerja guru yaitu 72,85 $(72,5 \leq X<94,5)$ dan persentase terbesar perolehan tersebut $(52,48 \%)$.

2. Hasil penelitian menunjukkan bahwa terdapat pengaruh positif dan signifikan: (a) kompetensi guru dan kepemimpinan kepala sekolah terhadap motivasi kerja guru SMK di Kabupaten Hulu Sungai Selatan, Kalimantan Selatan, baik secara sendiri-sendiri maupun bersama-sama dengan taraf signifikansi 0,038 ; 0,045; dan 0,001; (b) kompetensi guru, kepemimpinan kepala sekolah, dan motivasi kerja guru terhadap kinerja guru SMK di Kabupaten Hulu Sungai Selatan, Kalimantan Selatan, baik secara sendirisendiri maupun bersama-sama, dan secara langsung atau tidak langsung taraf signifikansi 0,$036 ; 0.003 ; 0,036 ; 0,000$; (0,038 dan 0,036); (0,045 dan 0,036).

\section{UCAPAN TERIMA KASIH}

Ucapan terima kasih penulis sampaikan kepada pihak-pihak yang telah membantu dalam penulisan tesis ini yang tidak dapat disebutkan satu persatu hingga tesis ini dapat diselesaikan dengan baik. Semoga segala bantuan yang telah diberikan mendapat pahala yang setimpal dari Allah Swt. Tesis ini masih jauh dari sempurna, namun semoga tesis ini dapat bermanfaat untuk penulis sendiri dan bagi peningkatan kinerja guru SMK khususnya di Kabupaten Hulu Sungai Selatan, Kalimantan Selatan. Amin.

\section{DAFTAR PUSTAKA}

Bhuono Agung Nugroho, 2005. Strategi jitu memilih metode statistik penelitian dengan SPSS. Yogyakarta: Andi Offset.

Byars, L. L., \& Rue, L. W., 1991. Human resources management. ( $3^{\text {rd }}$ ed). Boston: Irwin Inc

Data Nasional, 2009. Jumlah guru menurut golongan. (Diakses pada tanggal 11 Agustus 2011 dari http://tunas63.wordpress.com/2010/01 130/data-nasional-2009-jumlah-gurumenurut-golongan/).

Departemen Pendidikan Nasional, 2003. Undang-undang Nomor 20 tahun 2003, tentang Sistem Pendidikan Nasional. 2005. Undang-undang Nomor 14 tahun 2005, tentang Guru dan Dosen. 
Djemari Mardapi, (2004). Penyusunan tes hasil belajar. Yogyakarta: PPS UNY.

.2008. Teknik penyusunan instrumen tes dan nontes. Yogyakarta: Mitra Cendia Press.

E. Mulyasa, 2005. Menjadi kepala sekolah profesional, dalam konteks menyukseskan MBS dan KBK. Bandung: Remaja Rosdakarya.

, 2009. Standar kompetensi dan sertifikasi guru. Bandung : Remaja Rosdakarya.

Haryadi Sarjono \& Winda Julianita, 2011. Spss vs lisrel, sebuah pengantar aplikasi untuk riset. Jakarta. Salemba Empat.

Husaini Usman, 2006. Manajemen teori, praktek dan riset pendidikan. Jakarta: Bumi Aksara.

Imam Ghozali, 2001. Aplikasi analisis multivariate dengan program SPSS. Semarang: Badan Penerbit Universitas Diponegoro.

Kartini Kartono, 2010. Pemimpin dan kepemimpinan. apakah kepemimpinan abnormal itu ?. Jakarta: PT. RajaGrafindo Persada.

Laporan bulanan, 2011. Daftar nominatif tenaga edukatif, pembagian tugas guru dalam kegiatan proses belajar mengajar, Juli 2011, empat SMK Negeri di Kabupaten Hulu Sungai Selatan Propinsi Kalimantan Selatan.

Luthans, F., 2008. Organizational behavior. Singapura : The McGraw Hill Companies. Inc.

Martinis Yamin, \& Maisah, 2010. Standarisasi kinerja guru. Jakarta: GP Press.
Mitchell, T. R., \& Larson, J. R., jr., 1987. People in organizations, an introduction to organizational behavior $\left(3^{\text {rd }} \mathrm{ed}\right)$. Singapure : Mc Graw Hill Book Company.

M. Ngalim Purwanto, 2010. Administrasi dan supervisi pendidikan. Bandung: PT. Remaja Rosdakarya.

Singgih Santoso, 2000. SPSS versi 7.5. Mengolah data statistik secara profesional. Jakarta : PT. Elex Media komputindo.

Spencer, L. M, Jr., \& Spencer, S. M., 1993. Competence at work, model for superior performance. New York: John Wiley \& Sons, Inc.

Sugiyon, 2010. Statistika untuk penelitian. Bandung: AlfaBeta.

, 2011. Metode penelitian pendidikan (pendekatan kuantitaif, kualitatif, dan $\mathrm{R}$ $\& D)$. Bandung: AlfaBeta.

Suparlan, 2006. Guru sebagai profesi. Yogyakarta: Hikayat Publishing.

Triton P.B., 2006. SPSS 13 terapan: Riset statistik parametrik. Yogyakarta: Andi Offset

Universitas Negeri Yogyakarta, 2010. Pedoman Tesis dan Disertasi Program Pasca Sarjana Universitas Negeri Yogyakarta. Kementerian Pendidikan Nasional, Universitas Negeri Yogyakarta Program Pasca Sarjana, Yogyakarta.

Wardiman Djojonegoro, 1998. Pengembangan sumberdaya manusia melalui sekolah menengah kejuruan (SMK). Jakarta. PT. Jayakarta Agung Offset. 